\title{
Combining ability of superior cacao clones for assembling high productivity and disease resistant cocoa
}

\author{
Rubiyo $^{1 *}$, and Nicho Nurdebyandaru ${ }^{2}$ \\ ${ }^{1}$ Indonesian Center for Agricultural Technology Assessment and Development, Bogor, West Java \\ 16114, Indonesia \\ ${ }^{2}$ Indonesian Center for Agricultural Land Resources Research and Development, Bogor, West Java \\ 16114, Indonesia
}

\begin{abstract}
This research aimed to determine the potentiality of P1 and P2 as parents to produce superior strains of hybrid cacao by estimating general combining ability (GCA) and specific combining ability from crossed diallel among high yielding parents which are resistant to $P$. palmivora. The study was conducted at the Experimental Farm Sumber Asin, Malang, East Java, from 2010 to 2018. The research was arranged in Randomized Block Design (RBD) consisted of 10 hybrids and 5 parents so that the treatment used 15 genotypes. Each treatment consisted of 12 plants in triplicates. Resistance test on parents and F1 showed that all crossed combination strains were infected by pod rot disease $(P$. palmivora) with various intensity. The highest disease intensity was a strain combination of DR 1 x ICS 13 and the lowest one was ICS 13 and SCa 6. All crossed combination strains in the field had not shown symptoms of any pest infection. Cacao clones that have low GCA value based on the disease intensity were TSH 858, ICCRI 3 and SCa 6 . These clones have the potential to be used in the assembly of disease-resistant and high-yielding cocoa hybrids in the future.
\end{abstract}

\section{Introduction}

Cacao (Theobroma cacao L.) is one of the estate commodities that has an important role in the Indonesian economy. Indonesian cocoa production recorded in world trade has significantly declined from 440 thousand tons in 2011 to 270 thousand tons in 2017 [1]. Until 2020, the total area of cacao plantations reached 1,582,406 ha or decrease by $1.14 \%$ compared to 2019. Between 2011-2020, the average contribution of the cacao area was dominated by smallholder plantations, around $97.06 \%$ per year. This indicates that cacao still plays an important role both as a source of employment and income for farmers. In addition, the Ministry of Agriculture, through the Directorate General of Estate Crop will increase the area of cacao land by 740 ha and cacao seeds with the 2020 Plantation Area Development Program [2].

\footnotetext{
* Corresponding author: rubiyo63@gmail.com
} 
Cacao cultivation faces many obstacles including plant diseases and insect pests which potentially reduce the quality and quantity of cacao production. Cacao pod borer (CPB) is currently the major pest of cacao in Indonesia. Also, the main diseases of cacao in Indonesia are black pod rot disease caused by Phytopthora palmivora (Butl) and Vascular Streak Dieback (VSD). These diseases are reported attacking cacao in many cacaoproducing countries. In general, the losses due to black pod rot disease on cacao plantations in the field ranges from $20-30 \%$ per year [3]. In 1997, the pod rot infection decreased the world's total cacao production up to $44 \%$ per year [4].

Increasing production and improving the quality of Indonesian cacao can be done through intensification and extensification. The implementation of these two programs requires the availability of superior cacao seeds and seeds, thus programmatic development of superior cacao cultivars or clones needs to be carried out immediately, one of them by producing F1 hybrid seeds. According to Iswanto and Winarno [5] and Suhendi et al. [6], cacao breeding in Indonesia is aimed at finding superior planting material with the following characteristics: high yield potential, good seed quality, and resistance to important pests and diseases such as pod rot (P. palmivora). Cacao in Indonesia is generally developed vegetatively (noble cacao/edel cacao) and uses hybrid seeds (lindak cacao/bulk cacao) that causes narrower genetic variability. Also, breeding programs to obtain $P$. palmiviora resistant cultivars are the objectives of activities carried out in various cacaoproducing countries [4,7]. Nevertheless, progress has come to achieving these objectives is limited as a result of (i) low genetic diversity of cacao, (ii) the absence of standardized efficient screening and selection methods, (iii) ineffectiveness of breeding strategies, and (iv) the unavailability of basic information on genetics and mechanisms of resistance to $P$. palmivora in cacao germplasm.

It is necessary to use donor parents which are resistant to P. palmivora and recurrent parents which generated high yielding in Indonesia's conditions, to produce F1 hybrids that have both properties of resistance to P. palmivora and high yielding. In this study, we tried to evaluate several superior clones of lindak cacao which have been reported to have one or both properties such as Sca 6 , TSH 858, and ICCRI 3 [8,9,10]. In addition, to identify parent pairs that can produce F1 hybrids with the expected qualitative and quantitative characteristics, need to conduct a study estimating the combining ability and heritability of the resistance properties of the parents used.

Therefore, this study was conducted to determine the potential cacao parents ( $\mathrm{P} 1$ and P2) that potential to produce superior cacao hybrids (F1) by estimating the general combining ability (GCA) value of diallel crosses between parents which resistant to infection ( $P$. palmivora) and high-yielding parents. The evaluation was carried out on 1year-old F1 populations to observe various characters of resistance to $P$. palmivora infection.

\section{Materials and methods}

\subsection{Time and place}

The research was conducted at Sumber Asin Experimental Station, Malang, East Java of Indonesian Coffee and Cacao Research Institute (ICCRI) starting from 2010 - 2018. The selection of pairs to produce F1 hybrids was conducted at Kaliwining Experimental Station in Jember, East Java. 


\subsection{Parental cross $\mathrm{P} 1$ and $\mathrm{P} 2$ to produce $\mathrm{F} 1$ hybrids}

Parents of cacao clones used for crosses were: Sca 6, ICS 13, TSH 858, DR1, and ICCRI 3 (Table 1). These five parents were known to have good disease resistance and high production. Crosses using half diallel model to obtain 10 cross combinations with artificial cross-pollination (hand pollination).

Table 1. A half-diallel cross with five parents to produce F1 hybrids.

\begin{tabular}{|c|c|c|c|c|c|}
\hline & ICRI 3 & TSH 858 & DR1 & ICS 13 & SCA 6 \\
\hline ICRI 3 & - & $\times$ & $\times$ & $\times$ & $\times$ \\
\hline TSH 858 & & - & $\times$ & $\times$ & $\times$ \\
\hline DR1 & & & - & $\times$ & $\times$ \\
\hline ICS 13 & & & & - & $\times$ \\
\hline SCA 6 & & & & & - \\
\hline
\end{tabular}

The breeding of the crosses is made after the cacao pod from the cross is ripe ( 5 months from the time of crossing). Ripe cacao pods are marked by discoloration of pod skin from green to yellow. The seeds (F1) of the ripe cacao pods resulting from crosses then planted using media soil:sand:manure with ratio 2:1:1 in 20x30 cm plastic bag. After 6 months, cacao seedlings will be moved from the nursery and planted into the field.

\subsection{Test for $P$. palmivora infections on cacao plants}

The study was designed using a randomized block design (RBD) consisting of 10 hybrids and 5 parents so that the treatment consisted of 15 genotypes tested. Each treatment consisted of 12 plants which were replicated 3 times with a spacing of $3 \mathrm{~m} \times 3 \mathrm{~m}$. The temporary shade used was Moghania macrophylla and the permanent shade was Gliricidia sepium (Gamal). The variables observed were:

- Evaluation of the response of F1 plants to P. palmivora infection using the detached-leaf assay method,

- GCA analysis for resistance variables and various other quantitative characters, and

- Growth data including plant height and stem diameter of the cacao plant.

\subsection{Data analysis}

Six days after P. palmivora inoculation, the symptom of spotting on the tested cacao leaves was observed and disease intensity (DI) was calculated. Spotting was observed using symptom scoring according to the modified method of Fry [11] and Rubiyo et al. [12] as shown in Table 2. DI values were used to classify plants into five categories (Table 3 ). The calculation of disease intensity was determined by the formula:

$$
D I=\frac{\sum_{i=1}^{n} n \cdot v}{Z . N} \times 100 \%
$$

DI = disease intensity;

$\mathrm{n}$ = number of plants with a certain score value;

$\mathrm{v}=$ score of the i-th;

$\mathrm{Z}=$ highest score value; and

$\mathrm{N}=$ number of plants with scores 
Table 2. Score of symptoms, attack category and symptom description on cacao leaves due to $P$. palmivora infection.

\begin{tabular}{|c|c|c|}
\hline Score & Attack category & Description \\
\hline 0 & Healthy & No infection \\
\hline 1 & Very light & $<5 \%$ infected leaves \\
\hline 2 & Light & $\begin{array}{c}5-10 \% \text { infected leaves, chlorosis/necrosis, } \\
\text { no fallen leaf, already swollen lenticels }\end{array}$ \\
\hline 3 & Moderate & $\begin{array}{c}10-25 \% \text { infected leaves, chlorosis/necrosis, } \\
\text { fallen leaves, swollen lenticels }\end{array}$ \\
\hline 4 & Slightly heavy & $\begin{array}{c}25-50 \% \text { infected leaves, chlorosis/necrosis, } \\
\text { fallen leaves, swollen lenticels }\end{array}$ \\
\hline 5 & Heavy & $\begin{array}{c}50-75 \% \text { infected leaves, chlorosis/necrosis, } \\
\text { fallen leaves, swollen lenticels }\end{array}$ \\
\hline 6 & Very heavy & $\begin{array}{c}>75 \% \text { infected leaves, chlorosis/necrosis, } \\
\text { fallen leaves, swollen lenticels, dead } \\
\text { seedlings }\end{array}$ \\
\hline
\end{tabular}

Table 3. Classification of cacao resistance to P. palmivora infection based on disease intensity.

\begin{tabular}{|c|c|}
\hline Resistance level & Disease intensity (\%) \\
\hline Resistant & $0-30$ \\
\hline Slightly resistant & $31-50$ \\
\hline Moderate & $51-65$ \\
\hline Slightly susceptible & $66-80$ \\
\hline Susceptible & $81-100$ \\
\hline
\end{tabular}

\section{Results and discussions}

The result of the resistance test of parental and F1 in the laboratory showed that all the combined strains were infected with pod rot disease with varying disease intensity. The highest disease intensity occurred on a strain combination resulting from DR 1 x ICS 13 parental crossing and the lowest was a combination from crossing ICS 13 and Sca 6. Strain combination F1 of DR 1 x ICS 13 was originated from parents that were susceptible to pod rot disease therefore cross combination showed the highest DI indicating the lowest resistance compared to other combination strains (Table 4).

The combination strain with parent Sca6 showed a relatively low DI value except for the combination Sca 6 with TSH 858. Sca 6 clone originating from Ecuador was a clone with a strong resistance to pod rot disease $[13,14,15]$ so the resistance properties of Sca 6 were more dominant over the other clones except for TSH 858 clone.

This laboratory test showed DR1 x ICS 13 combination strain was slightly susceptible to pod rot disease with DI $>25 \%(25.48 \%)$ however the symptom of P. palmivora attack were not seen in 2-year-old plants during resistance test in the field. This suggests that there are environmental conditions that affect the resistance of this strain. 
Table 4. The disease intensity of cacao pod rot disease in laboratory test.

\begin{tabular}{|c|l|c|}
\hline No & Combination of parent crosses & Pod rot disease intensity (\%) \\
\hline 1 & ICCRI 3 X TSH 858 & 13.83 \\
\hline 2 & ICCRI 3 X DR1 & 15.49 \\
\hline 3 & ICCRI 3 X ICS 13 & 12.27 \\
\hline 4 & ICCRI 3 X Sca 6 & 8.25 \\
\hline 5 & TSH 858 X DR1 & 9.62 \\
\hline 6 & TSH 858 X ICS 13 & 11.70 \\
\hline 7 & TSH 858 X Sca 6 & 13.17 \\
\hline 8 & DR 1 X ICS 13 & 25.48 \\
\hline 9 & DR 1 X Sca 6 & 6.25 \\
\hline 10 & ICS 13 X Sca 6 & 4.44 \\
\hline
\end{tabular}

From these data combinations of crosses, it is shown that the clonal combinations showed resistance to $P$. palmivora disease at least until the age of cacao at the time of this study ( 2 years). This can be seen from the reality in the field that some clones around the cacao seedlings are infected by P. palmivora, although field conditions such as rainfall, air humidity, shade plants. and other environmental factors are sufficient to support the possibility of spreading the disease. Sumber Asin Experimental Station has the typical of medium highland-dry climate [9]. This condition likely less favorable or not optimal for spores of $P$. palmivora to germinate and infect cacao plants.

Stem diameter observation on 1-year-old cacao plants from crosses at Sumber Asin Experimental Station showed the diameters ranged from 26.54-37.91 mm. ICCRI 3 x ICS 13 hybrids produced the smallest diameter compared to other hybrids (Table 5). This indicates that there are variations in stem diameter in cacao plants in the field.

Table 5. Stem diameter and height of cacao hybrids plant

\begin{tabular}{|c|l|c|c|}
\hline \multirow{2}{*}{ No } & \multirow{2}{*}{ Parental cross combination } & \multicolumn{2}{|c|}{ Variable } \\
\cline { 3 - 4 } & & Stem diameter (mm) & Plant height (cm) \\
\hline 1 & ICCRI 3 X TSH 858 & 32.91 & 90.78 \\
\hline 2 & ICCRI 3 X DR1 & 29.33 & 97.27 \\
\hline 3 & ICCRI 3 X ICS 13 & 26.54 & 111.19 \\
\hline 4 & ICCRI 3 X Sca 6 & 35.76 & 98.61 \\
\hline 5 & TSH 858 X DR1 & 37.91 & 106.39 \\
\hline 6 & TSH 858 X ICS 13 & 35.04 & 102.76 \\
\hline 7 & TSH 858 X Sca 6 & 37.35 & 105.19 \\
\hline 8 & DR 1 X ICS 13 & 32.39 & 78.44 \\
\hline 9 & DR 1 X Sca 6 & 27.94 & 103.52 \\
\hline 10 & ICS 13 X Sca 6 & 36.64 & 119.06 \\
\hline
\end{tabular}

Based on the analysis of GCA influence on DI, TSH 858, Sca 6, and ICCRI 3 clones have lower GCA values compared to DR1 and ICS 13 (Table 6). Low GCA values are expected in the disease intensity variable $[7,16]$. This is because the lower the disease intensity, the more resistant the clones are to the infection of $P$. palmivora. Thus, in this case, a small GCA value means having a better combining ability (GCA) than the other clones. Sca 6 clone which has the lowest GCA (3.20) is defined as having better combining ability so it has the possibility to obtain better progeny in the next generation. Also, Sca 6 has the lowest disease intensity in comparison with the 4 others clones. The combination of Sca 6 with other parents which have low GCA on DI (better GCA), ICCRI 3 (13.83), and TSH 858 (12.93) might have hybrids that would have resistance properties to P. palmivora (Table 6). Moreover, Sca 6 was reported resistant to VSD and is recommended to be 
applied in area with high disease epidemic because can give higher yield than superior clones with higher productivity but susceptible to disease, including $P$. palmivora [17].

Table 6. General combining ability (GCA) value of five cacao clones cacao for the resistance to Phytopthora palmivora infection measured by disease intensity (\%).

\begin{tabular}{|l|c|c|}
\hline \multicolumn{1}{|c|}{ Clone } & Disease intensity (\%) & GCA on disease intensity \\
\hline ICCRI 3 & 20.42 & 13,83 \\
\hline TSH 858 & 22.39 & 12,93 \\
\hline DR1 & 18.39 & 18,03 \\
\hline ICS13 & 23.24 & 16,28 \\
\hline Sca 6 & 15.33 & 3,20 \\
\hline
\end{tabular}

According to Falconer [18], Falconer and Mackay [19], and Griffing [20], general combining ability (GCA) is an important indicator of potential value from pure strains for the cross combination of a hybrid. GCA is the result of the action of additive genes. The high variety of additives indicated the high role of additive gene action on the observed characters. Characters that are controlled by the action of additive genes can be fixated so the resistance selection can be done in the early generations. This is a very important opportunity and breakthrough for cacao plants considering that cacao is an annual plant that generally requires a long time to produce the expected clones or parents. Clones with low disease intensity and good GCA value like Sca 6 are likely to be used as a pollen source (male parent) to inherit the resistance trait. It is considered to choose the female parents with high-yield and large seed sizes to be crossed to obtain hybrids with characteristics both parents.

\section{Conclusions}

The intensity of pod rot disease by infection of $P$. palmivora were reported in all parental cross combinations in laboratory but not in the field. Therefore, combining ability of the parents is necessary to be assessed to determine which parents had the best resistance to pod rot disease. Because selecting parents is an important step in breeding programs. TSH 858 , ICCRI 3 and Sca 6 had low GCA values with relatively good result of agronomic parameters for all parental cross combination. We recommend these clones, especially the latter, as a materials for assembling cacao hybrids in the future.

\section{References}

1. International Cocoa Organization, Production of cocoa beans (ICCO Quarterly, Bulletin of Cocoa Statistics, XLV, 3, 2019)

2. Pusat Data dan Sistem Informasi Pertanian, Outlook Kakao 2020 (Pusdatin, Jakarta, 2020)

3. G.A.R. Wood, Establishment, in G.A.R. Wood, R.A. Lass (Eds), Cacao, 119-165 (Longman, London, 1985)

4. H.A.M. Van der Vossen, Strategies of Variety Improvement on Cacao with Emphasis on Durable Disease Resistance (INGENIC, Reading, 1997)

5. A. Iswanto, H. Winarno, Cacao breeding at RIEC Jember and the roll of planting material resistant to VSD and black pod, in P.J. Keane, C.A.J. Putter (Eds), Cacao Pest and Disease Management in Southeast Asia and Australasia, FAO Plant Production and Protection Paper 112, 163-169 (1992) 
6. D. Suhendi, H. Winarno, A.W. Susilo, Peningkatan produksi dan mutu hasil kakao melalui penggunaan klon baru, in Prosiding Simposium Kakao, Pusat Penelitian Kopi dan Kakao Indonesia, 4-5 October 2004, Yogyakarta, Indonesia (2005)

7. G.V.H. Jackson, J.G. Wright, Black pod and canker of cocoa (Pest Advisory Leaflet No. 7, Plant Protection Service, Secretariat of the Pacific Community, 2001)

8. D. Suhendi, S. Mawardi, H. Winarno, Pelita Perkeb. 21, 1-10 (2005)

9. A.W. Susilo, Pelita Perkeb. 27, 168-180 (2011)

10. A.W. Susilo, I. Anita-Sari, Pelita Perkeb. 30, 1-14 (2014)

11. W.E. Fry, Principles of Plant Disease Management (Academic Press Inc, London, 1982)

12. Rubiyo, A. Purwantara, D. Suhendi, Trikoesoemaningtyas, S. Ilyas, Sudarsono, Pelita Perkeb. 24, 95-113 (2008)

13. A. Iswanto, Winarno, D. Suhendi, Pelita Perkeb. 15, 81-90 (1999)

14. W. Philips-Mora, Studies on resistance to black pod disease (Phytophthora palmivora Butler) at CATIE, in Proceeding of International Workshop on the Contribution of Disease Resistance to Cacao Variety Improvement, 24-26 November 1999, Salvador, Bahia, Brazil (1999)

15. Rubiyo, A. Purwantara, Sri-Sukamto, Sudarsono, Pelita Perkeb. 24, 37- 49 (2008)

16. T. Lefeber, M. Janssens, F. Moens, W. Gobert, L.D. Vuyst, Appl. Enviromental Microbiol. 77, 6694-6698 (2011)

17. A.W. Susilo, S. Mawardi, Sudarsianto, Pelita Perkeb. 25, 76-85 (2009)

18. D.S. Falconer, Introduction to Quantitative Genetics, $2^{\text {nd }}$ (Longman Group Limited, London, 1985)

19. D.S. Falconer, T.F.C. Mackay, Introduction to Quantitative Genetics, 4th ed (Longman, Essex, 1996)

20. B. Griffing, Aust. J. Biol. Sci. 9, 463-493 (1956) 